\section{ECONOMIC MODERNIZATION IN A CHEPANG VLLAGE IN NEPAL}

Ganesh Man Gurung

\section{Introduction}

Among the various approaches to the study of change. "modernization" is a popular term in the social sciences. Various social scientists have attempted to define "modernization" (e.g., Lerner 1958; Rostow 1960; Moore 1966; Levy 1966) since the late 18th century when industrialization arose as a dominant force in western countries. The concept of modernization is also a concern of Indian sociologists and social anthropologists (Srinivas 1966; Dube 1966. 1970; Pandey 1976; Sachidanand 1976; etc.) in the Indian situation. By using their approach, a few foreign scholars (e.g., Tisinger 1970) have studied Nepali society.

Modernization means a process of rapid social change which has been used recently for understanding social phenomenon. Besides. this term is defined as "what is involved in modernization is total transformation of a traditional or pre-modern society into types of technology and associated social organization that characterizes the advanced economically prosperous and relatively politically stable nations of the Western World" (Moore 1965: 95). In other words, modernization has connoted industrialization. It has generally meant a process of sociocultural change in which less developed societies come into possession of characteristics common to more developed ones. So the basic theme of discussion about modernization is the change in the economic aspect as well as the cultural one.

Since the concept of modernization has been constructed to address the process of development in underdeveloped societies, it is unsuitable for primitive tribal societies. This is because primitive economy diverges qualitatively from the money and market economy of complex society. Tribal peoples are considered as living in unapproachable forest and hill areas, having therefore experienced less interaction with other peoples. The "modernization" process has a different meaning among these people. It means to raise their economy to a subsistence level, including the introduction of a certain amount of technology and the modification of the culture to adapt to the new economy.
Whereas in underdeveloped societies modernization is considered as indicated by the development and change up to the standards of industrialized, modernized or, in other words, "Western Societies," in the tribal world, it indicates the development and change of tribal societies up to the level of an underdeveloped stage.

The basic objective of this study is to analyze the process of modernization of the Chepang, a tribal people living in the middle hills west of Kathmandu. Nearly thirty-two thousand people in number, the Chepang are distributed in some of the hilly regions of of the Dhading.

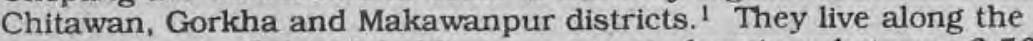
steeper slopes of the Mahabharat range at elevations between 2.500 and 4,000 feet above sea level.

The study takes into account various agents of modernization, such as the impact of roads, marketing centers, the Proja Development Programme, new means to communication, education and so forth, to analyze processes and stages of change from forest life to that of a peasantry, and from a primitive to a pre-modern stage stage. The data were recently collected from Ghairang Village of Mahadeo Panchayat in the Dhading district. ${ }^{2}$ It is about a three hour walk from Malekhu Bazaar on the Prithvi Highway.

\section{The Modernization Process}

In general, the socioeconomic structure of the Chepangs is markedly different from that of neighboring non-Chepang peoples, especially that of the Brahmins and Chetris. The main features of the Chepang economy are as follows:

(a) They have a forest and stream based economy. They still carry on the natural economy as a form of their primitive survival.

(b) Their technology is simple and indigenous.

(c) The unit of production and consumption is the family. It acts as an autonomous unit.

(d) There is an absence of profit-motive.

Like many tribal peoples in the world, the Chepangs lived a semi-nomadic existence, marked by hunting and gathering, fishing. and slash and burn cultivation. They used a variety of indigenous tools to glean their subsistence, including bows and arrows, snares, traps. baskets, hooks and nets, and poisons. Previously, their staple food consisted of honey, wild grains, wild bananas, and forest roots and tubers. 
They toil not, neither do they spin ... but living entirely upon wild fruits and the produce of chase ... They have bows and arrows of which the iron arrow-heads are procured from their neighbors but almost no other implements of civilization and it is in the very skillful snaring of the beasts of the field and fowls of the air that all their little intelligence is manifested [Hodgson 1948:45].

Even today, the Chepangs consume the fruits of chiur (bassia butyracea), khania (a kind of fig tree), and Newara (a kind of fern from which the young shoots are eaten).

They collect leaves and fruits of nettles, tangis, koirala flower (name of a tree, Bauhinia variegate), githa (the plant-dioscorea Sativa) Byakur (kind of creeper, the roots of which are eaten), chungia (the stem tendril and root are eaten), odal (stercuria villosa), tree from which fibre is obtained) and Bharlang (the shoot of which is a spiny shrub, the root is eaten). Ghitha bitter in taste, has to be boiled in ashes once and washed thrice to make it edible. And Bharlang which is poisonous has to be boiled thrice in ashes and washed seven times to make it eatable" [Varya 1972].

The Chepangs presently still collect insects to eat along with honey and wax. They collect ryank (a kind of wash), aringal (hornets) and ngol (a poisonous insect). They are conversant with the use of bows and arrows, and their hunting consists mostly of trapping and snaring animals with the assistance of dogs which accompany them on their wanderings. The animals which the Chapangs like to hunt are ghoral (wild Himalayan goat), mirga (deer) and banel (pig). They kill yasua (wild fowl), rutava (black crested pheasant and other small birds such as lingsherva (jureli), brit (kotero), manrangra (phista) and birds. Being good fishermen, the Chepangs fish throughout the year as a vital part of their subsistence economy.

They serve their food on the leaves and taparis (small plates made of leaves). This is interesting to note that they divide their food equally among the family members even to children. When they distribute their food they even count the foetus or unborn baby too, whose share goes to the mother [Thapa 1974:78].

All of these characteristics reflect the primitiveness of their economy. However, after the construction of highways such as the Prithvi Rajmarg to the north, the Mugling-Bharatpur highway to the west, the Tribhuvan Rajpath to the east, and the East-West highway to the south, the Chepang region lost its isolation. Nowadays the Chepang region is connected by highways running through it which enable them to visit roadside bazaars such as Malekhu. Mugling.
Bhandara, Manahari and Bharatpur. Consequently, their historically ecologically balanced society is undergoing rapid change.

The local people say that up to a century ago, the Chepangs were nomadic and wholly dependent on hunting, gathering and fishing. In this regard, Gaughley et al. (1971:77) writes that "the Chepangs started agricultural life only ... recently. About 120 years ago ... they used to live partly in the forest and caves." Hodgson (1948:45) notes that "they toil not, neither do they spin." Upreti (1967:29) estimates that they have been doing terrace cultivation for about 80 years. Rai and Chaudhary (1976:12) observe that the Chepang hunters and gathers must have been compelled to begin a settled life due to the problem of deforestation. In any case, their settled agrarian life is hardly a century old, resulting most probably when they came into contact with agrarian castes. On the other hand, the vanishing scope of hunting and gathering in increasingly exploited jungle made them into simple cultivators. Consequently, their natural economy was increasingly replaced by simple agriculture.

The characteristics of the Chapangs observed by Hodgson (1948) are gone today. Their economy is passing through the transitional phase from a natural economy to a simple agrarian one. However, the Chepangs living in Kachhar, the inaccessible interior, still preserve their traditional pattern of economy, since they are left free from interference by so-called "civilized people".

The Chepangs of Ghairang Village differ in many ways from the others of the Kachhar area, such as those of Tapang. Loling.

Majhkharka and Brushubang. In the latter locations, hunting, and slash and burn cultivation play a significant role in the lives of the villagers. But the Chepangs of Ghairang are in a better position. They have changed from shifting to sedentary cultivation.

Mahadeo Panchayat has a population of 5961 in approximately 985 houses. The households are divided into the following categories:

$\begin{array}{lr}\text { CHEPANG } & 259 \\ \text { BRAHMIN } & 82 \\ \text { MAGAR } & 83 \\ \text { CHETRI } & 43 \\ \text { NEWAR } & 10 \\ \text { GURUNG } & 29 \\ \text { TAMANG } & 452 \\ \text { UNTOUCHABLE } & 37\end{array}$

In Ghairang Village there are 92 Chepang, 3 Chetri and 4 Untouchable households.

It takes about three hours to walk on a narrow and rough footpath constructed by the villagers to Malekhu Bazaar on the Prithvi 
Highway. Malekhu Bazaar is the main marketing center. The Chepangs of Ghairang generally go there to sell their agricultural produce, including oranges, chiuri, amba, chaksi, bananas and seasonal vegetables such as tomatos, cucumbers and so forth. They also purchase their daily needs there. They come into contact with nontribals in the marketing center, from whom they learn about the larger world. For all these reasons the marketing center is an important part of their daily lives.

Agriculture is the main occupation of the villagers. There are several reasons for the central importance of agriculture in their economy. First, for a long time now they have been in contact with Brahmins and Chetris. Second, the Chepangs of Ghairang purchased paddy fields on credit from the Brahmins who were migrating into the plains area. Later, they paid the cost of their land from their agricultural income obtained by selling fruit, fowl, goats and vegetables. According to my observation, only five households out of 92 possessed no land and continued to practice their traditional patterns of subsistence such as gathering in the jungle. The rest of the Chepangs are agriculturalists and even hate their age-long traditional food gathering practices. However, they sometimes hunt deer in groups. Most of them possess both paddy fields and dry lands for maize and millet.

The Praja Development Programme was launched in 1977 for uplifting the Chepangs of Nepal. A field office of the Praja Development Programme of Dhading district is located in Mahadeo Panchayat near Ghairang Village. The Praja (Chepang) Development Office supplies the villagers with seeds, goats for hybridization, fruit plants, insecticides and chemical fertilizers. A primary school was also built in Ghairung by the program. It has 35 students and two teachers. In spite of their difficulties, the villagers share a positive attitude towards the education of their children. The problem of drinking water has also been solved at the present. Thus, the Praja Development Programme has made some significant contributions, but not without weaknesses.

Presently, agricultural production and domestic possessions are the main sources of income. However, five Chepang men received carpentry training, and eight women were trained under the Praja Development program. Two Chepangs work as postmen in the Talti Post Office of the Mahadeo Panchayat. Sometimes the Chepang find courage to go to the plains area and the roadside for employment.

Thus they have show an interest in wage and salaried labor.

Due to their contact and interaction with the non-tribals of Mahadeo Panchayat, the Chepangs of Ghairang have abandoned shifting cultivation and adopted settled cultivation. The economic structure of the Chepangs of Ghairang is based essentially on agricultural

production. The emergence of a market economy there resulted from the construction of the Prithvi Highway and the growth of marketing centers such as Malekhu and Bardanda. These are contributing both to agricultural production and to occupational changes among the people.

Their sale of agricultural commodities and purchase of daily needs has led to a change from an immobile economy to a mobile one and from one oriented towards subsistence to one oriented towards money. Gradually an eagemess towards eaming income from various means without depending essentially on agricultural production is emerging among the Chepangs of Ghairang. Due to the improvement of the communication system, including mass media and

transportation, the establishment of of primary education and the introduction of the Praja Development Program have all been able to contribute towards the path of modernization, acculturation, and the transformation of the social structure.

\section{Summary and Conclusion}

The major findings of this study can be summarized as follows:

(a) Much change has taken place in the traditional economic structure of the Chepangs as a result of a long period of interaction with non-tribals. They are now selling their products in the market. This interaction with outsiders leads them further in the process of modernization of their occupation and economy.

(b) Responsible factors for the modernization and gradual change in the Chepang region are construction of roads, growth of marketing centers, establishment of educational institutions and introduction of the Praja (Chepang) Development Programme.

(c) The traditional economic structure of the Chepangs is gradually proceeding towards a dynamic economic structure.

From the above discussion it has been found that the process of change presently taking place among the Chepangs is not

modernization. It is simply a change in the horizontal line from one place to another. Because of it, conflict and unrest are common features among the Chepangs of Nepal. 


\section{Notes}

1According to the record of Praja (Chepang) Development Offices, the numbers of Chepang by district are as follows:

$\begin{array}{ll}\text { Chitawan } & 13,210 \\ \text { Makawanpur } & 10,000 \\ \text { Dhading } & 6,480 \\ & 2,200\end{array}$

2I am grateful to Jeanet, who with great interest visited the Chepang areas for three days, for her comments in the preparation of this paper.

\section{References Cited}

Bista, Dor Bahadur

1980 People of Nepal (Revised edition). Kathmandu: Ratna Pustak Bhandar.

Caughley, R. C., B. M. Dahal, and C. M. Bandhu

1971 Notes on Chepang Culture. Journal of Tribhuvan University $6(1)$.

Dubey, S. M.

1966 Modernization Among the Tribes of North-Eastern India (Assam). In Traditions and Modernization, S. K.

Srivastava, ed.

1970 Comparative Study of Modernization Among the Khasis and Mikirs (Monography). Assam: Department of Sociology, Dibrugarh University.

Hodgson, B. H.

1848 On the Chepang and Kusunda Tribe of Nepal. Journal of the Asiatic Society of Bengal 17(2). Reprinted in Essays of the Language, Literature and Religion of Nepal and of the Language, L
Tibet, Pt. 2, 1957.

Lerner, D.

1958 The Passing of Traditional Society. Glencoe, Scotland: The Free Press of Glencoe.

Levy, M. J.

1966 Modernization and the Structure of Societies. Princeton, New Jersey: Princeton University Press.

Moore, W. L.

1965 Social Change. Englewood Cliffs: Prentice Hall International.

Rai, Navin $\mathrm{K}$.

1985 People of the Stones: The Chepangs of Central Nepal. Kathmandu: CNAS. Tribhuvan University.
Rai, Navin K. and Chaudhari

1975 Chepang Jati Ko Samajik Arthik Samunnati Servechhyan (Socio-Economic Development Survey of the Chepangs). Kathmandu: CEDA, Tribhuvan University.

Rostow, W. W.

1960 The Stages of Economic Growth, A Non-Communist Manifesto. London: Cambridge University Press.

Sachchidananna

1976 Tradition. Modernity and Modernization. In Tradition and Modernization, S. K. Srivastava, ed.

Srinavas, M. N.

1966 Sanskritization in Social Change in Modern India. Berkeley: University of California Press.

Thapa, B. B.

1974 Chepang Haru Sanga Kehi Din (A Few Days with the Chepangs). Madhuparka 7 (S. 78-68).

Tisinger, C. A

1970 The Modernization of Nepal: A Socio-Economic Perspective. Philadelphia: University of Pennsylvania Press.

Upreti, D. R.

1966 Chepang Bhanne Nepali Jati (Chepang a Nepali Ethnic Group), Hamro Sanskriti, pp. 29-33.

Varya, T. V.

1971 The Chepang. Rising Nepal, July 14. 